\title{
Soil Seed Bank and Plant Community Development in Passive Restoration of Degraded Sandy Grasslands
}

\author{
Renhui Miao ${ }^{1}$, Yongheng Song ${ }^{1}$, Zhaolin Sun ${ }^{1}$, Meixia Guo ${ }^{2}$, Zhenxing Zhou ${ }^{1}$ \\ and Yinzhan Liu ${ }^{1, *}$ \\ 1 International Joint Research Laboratory for Global Change Ecology, College of Life Sciences, \\ Henan University, Kaifeng 475004, China; miaorenhui@henu.edu.cn (R.M.); \\ songyonghenghd@163.com (Y.S.); sunzlyes@163.com (Z.S.); zzhouhenu@163.com (Z.Z.) \\ 2 Graduate School of the Chinese Academy of Sciences, Beijing 100039, China; gmxsdnu@126.com \\ * Correspondence: liuyinzhan@henu.edu.cn; Tel.: +86-371-2388-5016
}

Academic Editors: Eric Vaz and Jamal Jokar Arsanjani

Received: 14 March 2016; Accepted: 17 June 2016; Published: 21 June 2016

\begin{abstract}
To evaluate the efficacy of passive restoration on soil seed bank and vegetation recovery, we measured the species composition and density of the soil seed bank, as well as the species composition, density, coverage, and height of the extant vegetation in sites passively restored for $0,4,7$, and 12 years (S0, S4, S7, and S12) in a degraded grassland in desert land. Compared with S0, three more species in the soil seed bank at depths of $0-30 \mathrm{~cm}$ and one more plant species in the community was detected in S12. Seed density within the topsoil $(0-5 \mathrm{~cm})$ was five times higher in $\mathrm{S} 12$ than that in S0. Plant densities in S7 and S12 were triple and quadruple than that in S0. Plant coverage was increased by 1.5 times (S4), double (S7), and triple (S12) compared with S0. Sørensen's index of similarity in species composition between the soil seed bank and the plant community were high (0.43-0.63), but it was lower in short-term restoration sites (S4 and S7) than that in no and long-term restoration sites (S0 and $\mathrm{S} 12$ ). The soil seed bank recovered more slowly than the plant community under passive restoration. Passive restoration is a useful method to recover the soil seed bank and vegetation in degraded grasslands.
\end{abstract}

Keywords: desertification; grazing exclusion; passive restoration; Sørensen's index of similarity (IS)

\section{Introduction}

Desertification of sandy areas in Northeast China, which is primarily triggered by overgrazing [1,2], poses a serious threat to ecosystem structure and function, resulting in reduced productivity [3]. Restoration methods such as passive restoration (i.e., removing domestic grazers) and active restoration (i.e., replanting target plant) have been widely used in degraded sandy grasslands [4-7]. Recently, some ecologists have documented that passive restoration of degraded lands should be considered first because passive restoration relies on the natural succession of a regressive ecosystem to drive recovery without anthropogenic help, which has also excluded the disturbance of domestic animals (i.e., cattle, sheep) [8-10]; thus, the cost is much cheaper than the active method. In addition, passive restoration methods are as effective as active restoration [11,12]. Thus, passive restoration has mostly been employed in degraded sandy grasslands of semi-arid regions $[1,2,13]$.

Previous studies of passive restoration in degraded ecosystems have found that passive restoration had positive [14-17], neutral [18], or even negative effects [19] on the species composition and density of the soil seed bank, as well as on the species composition, density, coverage, and mean height of vegetation. The different results mainly depended on the variety in seed production and emergence capacity, plant growth and dispersal, and the ratio of weeds to grass across the different grasslands [15]. 
The similarity between the species composition of the soil seed bank and vegetation may increase [20], decrease [21], or not change [15,22] after disturbance has been excluded from degraded grasslands. The contradictory results were attributed to variations in (1) the plant dispersal capacity; (2) the proportion of the extant plants derived from the soil seed bank (vs. dispersal into the site from outside); (3) the production and species richness of mature vegetation; and (4) the relative proportions of persistent soil seed bank. Previous studies have reported that high similarity occurred in communities with weak plant dispersal capacity and high vegetation productivity and species richness, whereas low similarity occurred under the opposite conditions [23-25]. However, understanding of the development of these ecosystem characteristics over time is still limited for degraded, semi-arid sandy grasslands managed using passive restoration.

A chronosequence of sites in Inner Mongolia under passive restoration method $(0,4,7$, and 12 years) were employed to quantify the recovery and similarity of the soil seed bank and vegetation. The objective of this study was to quantify the effects of passive restoration on (1) the species composition and density of the soil seed bank; (2) the species composition, density, coverage, and mean height of extant vegetation; and (3) the Sørensen's index of similarity (IS) between the soil seed bank and vegetation community. The results can provide a basis for understanding about the passive restoration effects on the soil seed bank and vegetation recovery, and will inform and promote policy made for protection and restoration in degraded grasslands.

\section{Materials and Methods}

\subsection{Field Site}

The study was conducted at the Wulanaodu Experimental Station of Desertification $\left(43^{\circ} 02^{\prime} \mathrm{N}\right.$, $119^{\circ} 39^{\prime} \mathrm{E}, 480 \mathrm{~m}$ a. s. 1.) in the western part of Horqin Sandy Land in Northeastern Inner Mongolia, China. The climate is semi-arid continental, with a mean annual precipitation of $340.5 \mathrm{~mm}$ and more than $70 \%$ of this precipitation occurred during the growing season (from May to September). Mean annual pan evaporation is $2000-2500 \mathrm{~mm}$, six to seven times greater than the annual rainfall amount. Average annual temperature is $6.3^{\circ} \mathrm{C}$, and the coldest and warmest months are January and July, with mean temperatures of $-14.0^{\circ} \mathrm{C}$ and $23.0^{\circ} \mathrm{C}$, respectively. Mean annual wind velocity is $4.4 \mathrm{~m} \cdot \mathrm{s}^{-1}$, and wind direction is predominantly northwestern. Gale days $\left(>20 \mathrm{~m} \cdot \mathrm{s}^{-1}\right.$ ) occur 21-80 times per year, with the windy season generally occurring from early April to late May. The native dominant plant community types were the Caragana microphylla community, the Cleistogenes squarrosa community, the Leymus chinensis-rank grass community, the Arundinella hirta-Hemarthia altissima community, the Spodiopogon sibiricus-rank grass community, the A. hirta-rank grass community, the Phragmites communis-rank grass community, the L. chinensis community, and the H. altissima-P. communis community [26]. The original communities have changed greatly following centuries of exploitation and over-grazing. The extant vegetation in degraded grassland is dominated by the target plant (C. microphylla), pioneer plants (Artemisia halodendron, A. frigida, Bassia dasyphylla, Corispermum thelelegium, and Agriophyllum squarrosum), and ruderal species (Setaria viridis and Chloris virgate).

In the Horqin Sandy Land, grazing was the main disturbance that led to long-term serious land degradation. Free grazing intensity was $4.5-5.0$ sheep ha ${ }^{-1}$ since the mid-1950s, which seriously exceeded a moderate grazing rate of 1.0-1.5 sheep ha ${ }^{-1}$ in this area, and induced the amounts of sand dunes. Passive restoration areas of at least $50 \mathrm{~m} \times 50 \mathrm{~m}$ were established in 2000, 2005, and from 2008 to 2012. The areas were fenced with 1.2-m-high cement blocks piled together with wire netting ( $1 \mathrm{~m}$ high $\times 3 \mathrm{~m}$ wide) to completely exclude livestock grazing since restoration established. This produced a chronosequence of sites that were 4, 7, and 12 years old by 2012 (referred to as S4, $\mathrm{S} 7$, and S12, respectively). Meanwhile, freely grazing sites were treated as the control treatment (S0). The distance between two adjacent restored sites is at least $400 \mathrm{~m}$. 


\subsection{Sampling Design and Procedure}

In April 2012, a control (S0) and three restoration (S4, S7, and S12) levels were selected as the experimental treatments, and the objective reference community (merely mowing in the winter) were dominated as the $C$. microphylla community, the L. chinensis community, the Cleistogenes squarrosa community, and the A. hirta community. Three sand dunes within each treatment area (as three replicates) were randomly selected as the research sites. The sand dunes had a similar soil texture and topography. A plot $(10 \mathrm{~m} \times 30 \mathrm{~m})$ was set up in the middle of the windward slope of each sand dune. Ten sampling quadrats $(1 \mathrm{~m} \times 1 \mathrm{~m})$ were randomly established in each plot, for a total of 120 quadrats (four treatments $\times$ three replicates $\times$ ten quadrats). In late April 2012, after the windy season but prior to the rainy season, soil samples were collected from each quadrat at four depths $(0-5,5-10$, $10-20$, and 20-30 cm) with a 7-cm diameter soil auger following with a previous study in this area [27]. A total of 480 soil samples (120 quadrats $\times 4$ depths) were collected and air-dried. The soils were passed through a $0.5-\mathrm{mm}$ sieve, and the seeds were picked out and identified to the species level by comparing with seeds collected from living plants in 2011. Any seeds that could not be identified were identified using a germination experiment in trays $(16 \mathrm{~cm}$ in diameter $\times 1 \mathrm{~cm}$ deep) in a greenhouse. All seeds were made viable using the "terazolium dyeing method" before germination [28]. A plant survey was conducted in late July 2012 at the peak of the growing season. A quadrat of $1 \mathrm{~m} \times 1 \mathrm{~m}$ quadrat was established at a distance of $50 \mathrm{~cm}$ from each soil seed sampling quadrats, and plant species were counted in each quadrat. We considered a plant shoot to be an individual plant for our species density calculations. Plant coverage was measured using a metal frame of $1 \mathrm{~m} \times 1 \mathrm{~m}$ with 100 equally distributed grids above the quadrat. The mean plant height was calculated from ten random height measurements, with height measured from the base of the plant (ground level) to the tip of the plant.

\subsection{Data Analysis}

The similarity of the species composition between the soil seed bank and vegetation community was calculated using the binary Sørensen index of similarity (IS) [29] with the flowing equation. Because the soil seed bank can only sample as volume, and the vegetation is calculated as area, which is a different sample method, it is difficult to compare the data, as they do not have the same technical sampling.

$$
I S=\left(\frac{2 C}{A+B}\right) \times 100 \%
$$

where $C$ is the number of species that the soil seed bank and plant community had in common, and $A$ and $B$ are the total number of species in the soil seed bank and plant community, respectively.

One-way ANOVA was used to compare the density of the soil seed bank, the density, coverage, and mean height of the plant, as well as the IS among the four treatments. Differences between each pair of treatments were tested with a post hoc Tukey HSD at a $p<0.05$ level. Normal distribution and homogeneity of variances were examined by the Shapiro-Wilk test and Levene's test before the above analysis was conducted. Statistical analyses were performed with the SPSS 16.0 software package (SPSS Inc., Chicago, IL, USA).

\section{Results}

\subsection{Soil Seed Bank Recovery}

The soil seed bank contained eight species from five families. All species were annual plants except for C. microphylla (a shrub) found in S12, which is the typical species of the target community. Species number was increased from three in S0 to five, four, and six in S4, S7, and S12, respectively (Table 1). The seed density from 0 to $30 \mathrm{~cm}$ was five times higher in $\mathrm{S} 12$ than that in S0, primarily because of the elevated seed number in the topsoil $(0-5 \mathrm{~cm})$, which explained $96 \%$ of the variation on soil seed density (Figure 1). 


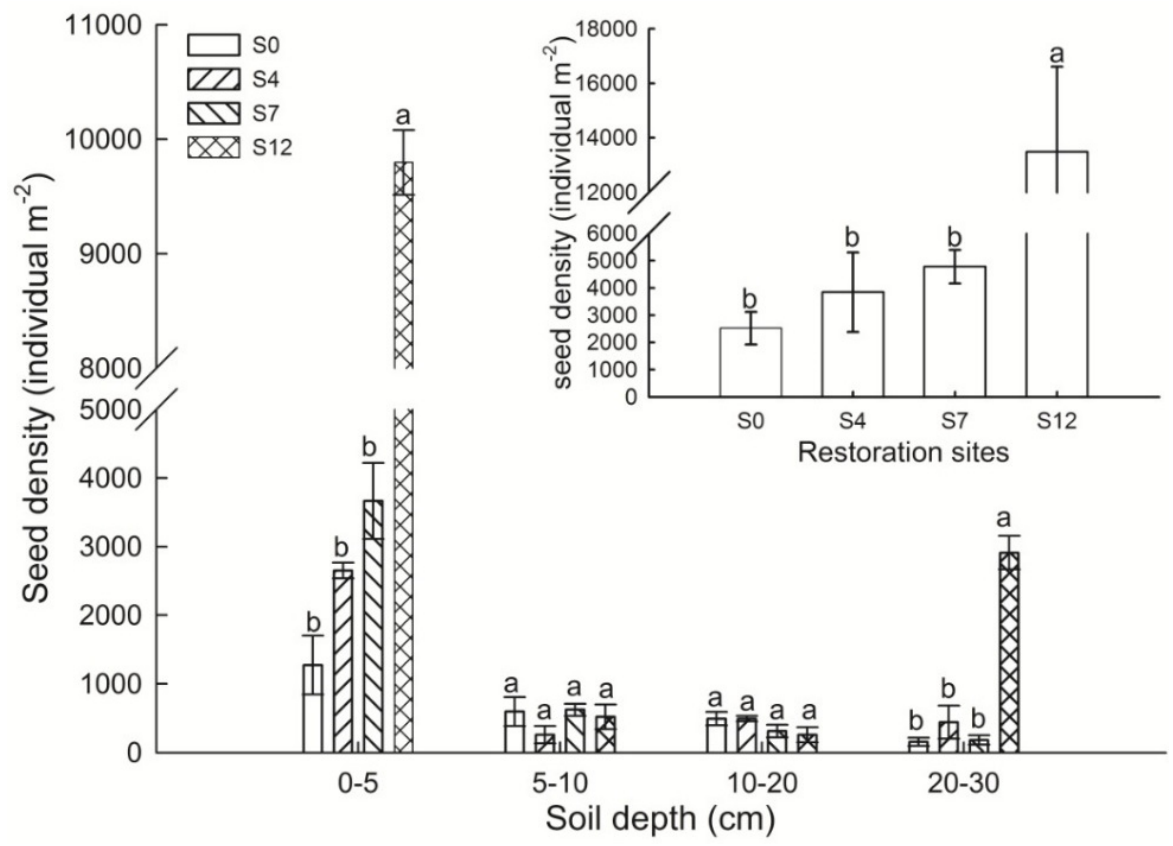

Figure 1. Soil seed density (individual $\mathrm{m}^{-2}$ ) at different soil depths $(\mathrm{cm})$ and sites (S0, S4, S7, and S12). Insert chart shows total soil seed density for $0-30 \mathrm{~cm}$. Different letters indicate a significant difference $(p<0.05)$.

Table 1. List of species recorded in the soil seed bank and vegetation community under the four treatments. +: present in the research sites; -: absent in the research sites.

\begin{tabular}{|c|c|c|c|c|c|c|c|c|c|}
\hline \multirow{2}{*}{ Species } & \multirow{2}{*}{ Family } & \multicolumn{4}{|c|}{ Soil Seed Bank } & \multicolumn{4}{|c|}{ Vegetation } \\
\hline & & So & S4 & S7 & $\mathrm{S} 12$ & So & S4 & S7 & S12 \\
\hline Aristida adscensionis & Poaceae & - & + & + & + & + & + & + & + \\
\hline Artemisia arenaria & Compositae & - & - & - & - & + & + & - & - \\
\hline Atraphaxis bracteata & Polygonaceae & - & + & - & - & - & - & - & - \\
\hline Agriophyllum squarrosum & Amaranthaceae & + & + & + & + & + & + & - & - \\
\hline Bassia dasyphylla & Amaranthaceae & - & - & - & + & + & - & + & + \\
\hline Chenopodium acuminatum & Amaranthaceae & - & - & - & - & - & - & + & + \\
\hline Corispermum candelabrum & Amaranthaceae & + & - & + & + & + & + & + & + \\
\hline Cuscuta chinensis & Convolvulaceae & - & - & - & - & - & + & + & + \\
\hline Caragana microphylla & Leguminosae & - & - & - & + & + & + & - & + \\
\hline Carduus nutans & Compositae & - & - & - & - & + & + & - & + \\
\hline Cleistogenes squarrosa & Poaceae & - & - & - & - & - & - & + & - \\
\hline Cynanchum thesioides & Apocynaceae & - & - & - & - & + & + & + & + \\
\hline Chloris virgata & Poaceae & - & - & - & - & - & - & + & - \\
\hline Diarthron linifolium & Thymelaeaceae & - & + & - & - & + & + & + & - \\
\hline Digitaria sanguinalis & Poaceae & - & - & - & - & + & + & + & + \\
\hline Echinops gmelinii & Compositae & - & - & - & - & - & + & - & - \\
\hline Euphorbia humifusa & Euphorbiaceae & - & - & - & - & + & + & + & + \\
\hline Eragrostis minor & Poaceae & - & - & - & - & - & - & + & + \\
\hline Hedysarum fruticosum & Leguminosae & - & - & - & - & - & + & - & - \\
\hline Lespedeza davurica & Leguminosae & - & - & - & - & + & + & - & + \\
\hline Lactuca indica & Compositae & - & - & - & - & - & - & - & + \\
\hline Rochelia leiosperma & Boraginaceae & - & - & - & - & - & - & + & - \\
\hline Salsola ruthenica & Amaranthaceae & - & - & - & - & - & - & + & + \\
\hline Setaria viridis & Poaceae & + & + & + & + & + & + & + & + \\
\hline Tribulus terrestris & Zygophyllaceae & - & - & - & - & + & + & - & - \\
\hline
\end{tabular}




\subsection{Plant Recovery}

We counted 24 species of plants from nine families, with 14 species in S0, 16 in S4, 15 in S7, and 15 in $\mathrm{S} 12$ (Table 1). The dominant families were Poaceae (six species), Amaranthaceae (five species), and Asteraceae (four species). Only C. microphylla and Cleistogenes squarrosa were typical species of the target community. The rest were pioneer species (e.g., B. dasyphylla, Corispermum thelelegium) and ruderals (S. viridis and C. virgate) (Table 1). Annuals species (i.e., Corispermum candelabrum, S. viridis) accounted for $57 \%$ plant density in S0,50\% in S4, 80\% in S7, and 67\% in S12. Compared with S0, plant density was doubled in S7 and tripled in S12. Plant coverage was increased by 1.18 and 1.99 times in S7 and S12, respectively, and plant height was increased by 0.72 and 1.22 times in S4 and S7 compared with S0 (Figure 2).

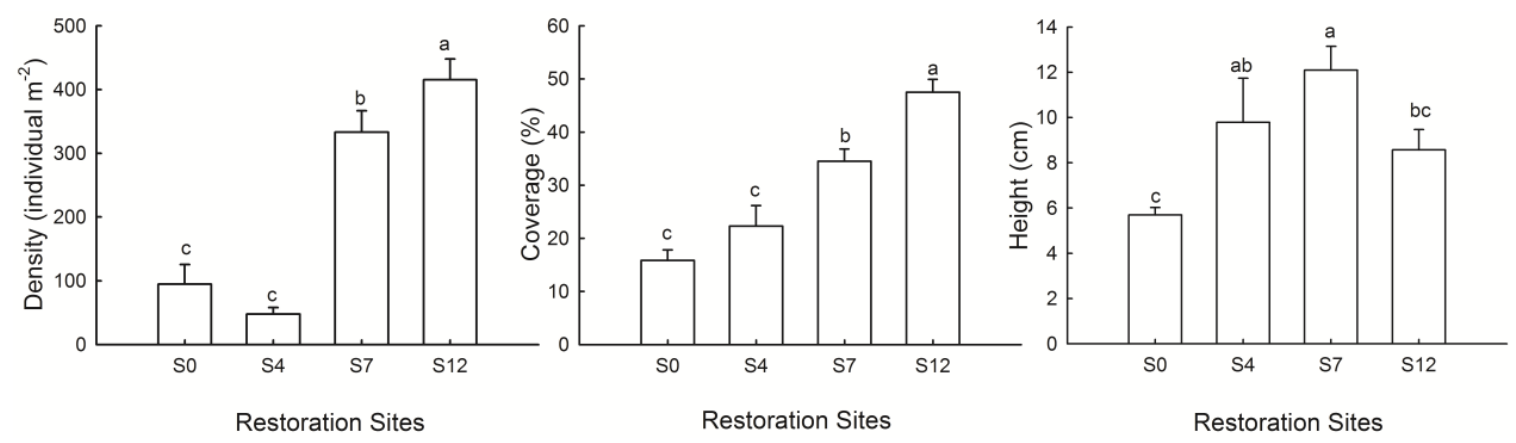

Figure 2. Density (individual $\mathrm{m}^{-2}$ ), coverage (\%), and mean height $(\mathrm{cm})$ of vegetation at the sites $(\mathrm{S} 0, \mathrm{~S} 4, \mathrm{~S} 7$, and S12). Different letters indicate a significant difference $(p<0.05)$.

\subsection{Restoration Effects on IS Values}

The IS values were generally high (from 0.43 to 0.63 ); however, IS decreased in non-chronological order with $\mathrm{S} 0>\mathrm{S} 12 \geqslant \mathrm{~S} 4 \geqslant \mathrm{~S} 7$ (where $>$ indicates a significant difference, and $\geqslant$ indicates a slight but not significant difference at $p=0.05$ ) (Figure 3 ).

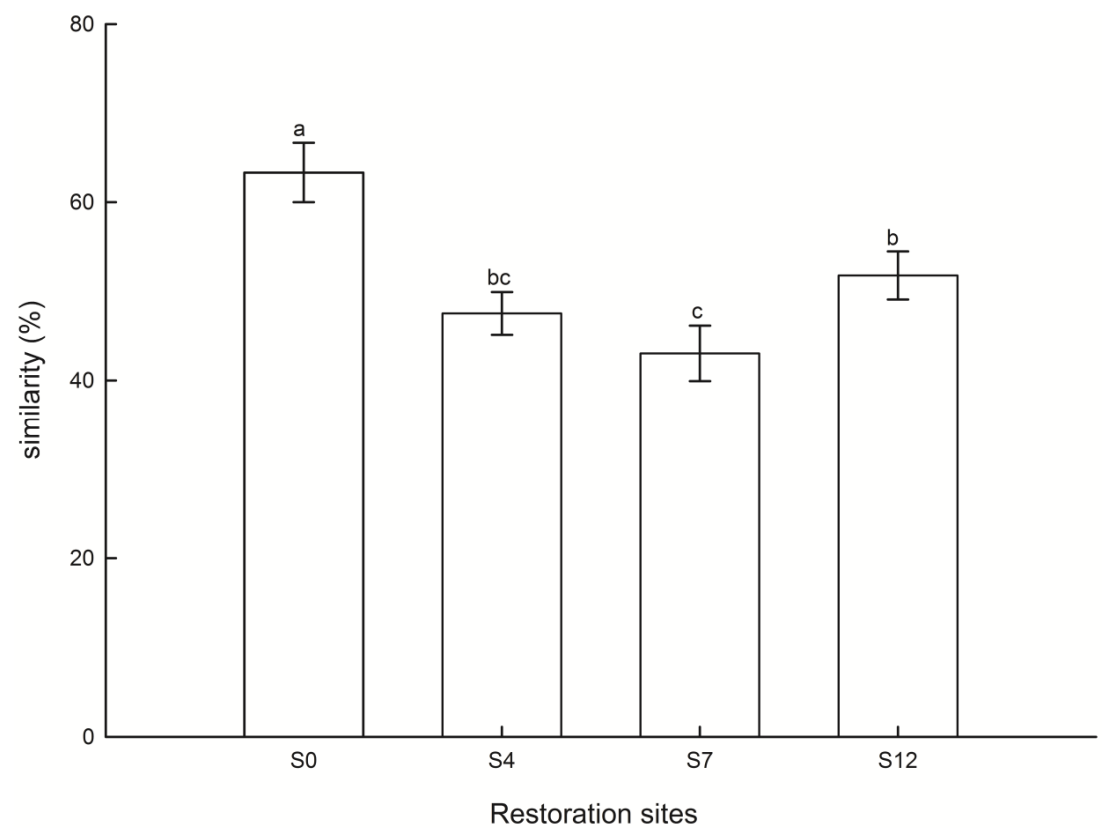

Figure 3. Sørensen similarity index between the soil seed bank and vegetation species composition at the sites (S0, S4, S7 and S12). Different letters indicate a significant difference $(p<0.05)$. 


\section{Discussion}

\subsection{Soil Seed Bank Recovery}

Successful ecosystem restoration primarily depends on the suitability and adaptability of the vegetation [30]. Plants regrow from seeds in the soil seed bank and extant plant reproduction, or are introduced by dispersal [31,32]; thus, the characteristics of the soil seed bank are important in determining the regeneration potential and resilience of the target community $[17,33,34]$. Our findings suggest that passive restoration can increase the number of species and their seed density in the soil seed bank, increasing ecosystem resilience [34-36]. However, Sun et al. (2005) and Li et al. (2012) observed an opposite effect of passive restoration on seed density [17,37]. These conflicting results may be attributed to the differences in seed sources and persistent seed bank reserves at different research sites $[29,38]$. Our findings show that the soil seed bank had partially recovered, but that restoration is a relatively slow, long-term process.

\subsection{Plant Recovery}

Plant community composition, density, and coverage are indicators for the restored lands extant vegetation evaluation $[7,39]$. We found that passive restoration significantly increased plant density, coverage, and slightly increase the plant height; these increased plant community characters can also change the species composition of the soil seed bank by increasing seed production [40]. The results are consistent with Fernández-Lugo (2009), Jeddi \& Chaieb (2010), and Li et al. (2012), who also investigated sandy grasslands [16,17,41]. Fernández-Lugo (2009) and Gomaa (2012) argued that grazing cessation and microhabitat improvements (mainly increased soil nutrient and water availability) altered the proportions of the dominant species and thus increased plant density, coverage, and height [41,42]. At our sites, the target species (C. microphylla and C. Squarrosa) are still present, essentially priming the sites for restoration. However, the recovery of the soil seed bank is slower than that of the plant community in our study, because plants regrew from both the soil seed bank and seeds dispersed from the surroundings, as observed in other restored sandy grasslands [26].

\subsection{Similarity in Species Composition between the Soil Seed Bank and Vegetation}

The IS values in all of our sites are higher than those in previous grassland studies [28,29], possibly because of differences in the ratio of perennials to annual species (IS typically decreases with an increasing ratio of perennial to annual species) [1,42]. Lower IS values in S4 and S7 comparing with $\mathrm{S} 0$, partially because the dormancy seed would not regenerate easily without dormancy breaking, indicating that during initial recovery, new species which are not present in the soil seed bank can be added through dispersal from the surrounding area. These results suggest that the species composition of the soil seed bank can be predicted with extant vegetation to some degree, and the recovery of soil seed bank and vegetation needs a relatively long period.

\section{Conclusions}

Our findings suggest that (1) long-term (12 years) passive restoration management can increase the species number and density of soil seeds, but short-term management (4 and 7 years) had minimal effects on these characteristics; (2) passive restoration can increase the species number, density, and coverage of the target vegetation community; and (3) the recovery of the soil seed bank was slower than that of the plant community. Our study has proved that passive restoration is a beneficial method for sandy grasslands management. Nonetheless, restoration interventions such as direct seeding and planting improve both the regeneration of plant species and land cover.

Acknowledgments: This work was supported by the National Natural Science Foundation of China (31200375, 31200408, 31300363, 31570429). We thank Xuehua Li, Yongming Luo, and Hongmei Wang for assistance in the field investigation and in the writing of the paper. 
Author Contributions: Renhui Miao conducted this experiment and wrote the manuscript; Meixia Guo revised and rewrote a large part of this manuscript; Yongheng Song, Zhaolin Sun and Zhenxing Zhou revised the manuscript. Yinzhan Liu designed the experiments and was responsible for data analysis.

Conflicts of Interest: The authors declare no conflict of interest.

\section{References}

1. Zhao, L.P.; Su, J.S.; Wu, G.L.; Gilet, F. Long-term effects of grazing exclusion on aboveground and belowground plant species diversity in a steppe of the Loess Plateau, China. Plant Ecol. Evol. 2011, 144, 313-320. [CrossRef]

2. Li, X.L.; Gao, J.; Brierley, G.; Qiao, Y.M.; Zhang, J.; Yang, Y.W. Rangeland degradation on the Qinghai-Tibet Plateau: Implications for rehabilitation. Land Degrad. Dev. 2013, 24, 72-80. [CrossRef]

3. Ding, Y.J.; Mu, M.; Zhang, J.Y.; Jiang, T.; Zhang, T.J.; Wang, C.Y.; Wu, L.X.; Ye, B.S.; Bao, M.Z.; Zhang, S.Q. Impacts of Climate Change on the Environment, Economy, and Society of China. Climate and Environmental Change in China: 1951-2012; Springer: Berlin, Germany, 2015.

4. Cao, C.Y.; Jiang, D.M.; Teng, X.H.; Jiang, Y.; Liang, W.J.; Cui, Z.B. Soil chemical and microbiological properties along a chronosequence of Caragana microphylla Lam. plantations in the Horqin sandy land of Northeast China. Appl. Soil Ecol. 2008, 40, 78-85. [CrossRef]

5. Wu, G.L.; Li, W.; Zhao, L.P.; Shi, Z.H. Artificial management improves soil moisture, C, N and P in an alpine sandy meadow of western China. Pedosphere 2011, 21, 407-412. [CrossRef]

6. Jeddi, K.; Chaieb, M. Restoring degraded arid Mediterranean areas with exotic tree species: Influence of an age sequence of Acacia salicina on soil and vegetation dynamics. Flora 2012, 207, 693-700. [CrossRef]

7. Miao, R.H.; Jiang, D.M.; Musa, A.; Zhou, Q.L.; Guo, M.X.; Wang, Y.C. Effectiveness of shrub planting and grazing exclusion on degraded sandy grassland restoration in Horqin sandy land in Inner Mongolia. Ecol. Eng. 2015, 74, 164-173. [CrossRef]

8. Ren, H.; Du, W.B.; Wang, J.; Yu, Z.Y.; Guo, Q.F. The natural restoration of degraded rangeland ecosystem in Heshan hill land. Acta Ecol. Sin. 2007, 27, 3593-3600.

9. Wu, G.L.; Liu, Z.H.; Zhang, L.; Chen, J.M.; Hu, T.M. Long-term fencing improved soil properties and soil organic carbon storage in an alpine swamp meadow of western China. Plant Soil 2010, 332, 331-337. [CrossRef]

10. Zahawi, W.A.; Reid, J.L.; Holl, K.D. Hidden costs of passive restoration. Restor. Ecol. 2014, 22, $284-287$. [CrossRef]

11. Bradshaw, A. The use of natural processes in reclamation-Advantages and difficulties. Landsc. Urban Plan 2000, 51, 89-100. [CrossRef]

12. Prach, K.; Hobbs, R.J. Spontaneous succession versus technical reclamation in the restoration of disturbed sites. Restor. Ecol. 2008, 16, 363-366. [CrossRef]

13. Wang, Z.J.; Wang, S.X.; Pan, Z.B.; Guo, Y.Z.; Chen, Y.Y. Influence of different recover measures on species structure and variety in Mu Us sandy land. Chin. J. Ecol. 2005, 24, 464-466.

14. Liu, M.Z.; Jiang, G.M.; Yu, S.L.; Li, Y.G.; Li, G. The role of soil seed banks in natural restoration of the degraded Hunshandak Sandlands, Northern China. Restor. Ecol. 2009, 17, 127-136. [CrossRef]

15. Shang, Z.H.; Yang, S.H.; Wang, Y.L.; Shi, J.J.; Ding, L.M.; Long, R.J. Soil seed bank and its relation with above-ground vegetation along the degraded gradients of alpine meadow. Ecol. Eng. 2016, 90, 268-277. [CrossRef]

16. Jeddi, K.; Chaieb, M. Changes in soil properties and vegetation following livestock grazing exclusion in degraded arid environments of South Tunisia. Flora 2010, 205, 184-189. [CrossRef]

17. Li, Y.Y.; Dong, S.K.; Wen, L.; Wang, X.X.; Wu, Y. Soil seed banks in degraded and revegetated grasslands in the alpine region of the Qinghai-Tibetan Plateau. Ecol. Eng. 2012, 49, 77-83. [CrossRef]

18. Meissner, R.A.; Facelli, J.M. Effects of sheep exclusion on the soil seed bank and annual vegetation in chenopod shrublands of South Australia. J. Arid Environ. 1999, 42, 117-128. [CrossRef]

19. Russi, L.; Cocks, P.S.; Roberts, E.H. Seed bank dynamics in a Mediterranean grassland. J. Appl. Ecol. 1992, 29, 763-771. [CrossRef]

20. Ma, M.J.; Zhou, X.H.; Du, G.Z. Role of soil seed bank along a disturbance gradient in alpine meadow on the Tibet plateau. Flora 2010, 205, 128-134. [CrossRef] 
21. Ungar, I.A.; Woodell, S.R.J. Similarity of seed banks to aboveground vegetation in grazed and ungrazed salt marsh communities on the Gower Peninsula, South Wales. Int. J. Plant Sci. 1996, 157, 746-749. [CrossRef]

22. Zhao, L.P.; Cheng, J.M.; Su, J.S. The role of soil seed bank in vegetation succession under grazing exclusion in Stipa bungeana grasslands on the Loess Plateau. Acta Pratacult. Sin. 2012, 21, 38-44.

23. Bossuyt, B.; Hermy, M. Seed bank assembly follows vegetation succession in dune slacks. J. Veg. Sci. 2004, 15, 449-456. [CrossRef]

24. Li, Y.L. Floristic composition of vegetation and the soil seed bank in different types of dunes of Kerqin steppe. Arid Land Res. Manag. 2004, 18, 283-293. [CrossRef]

25. Kristine, N.H. A review of similarity between seed bank and standing vegetation across ecosystems. Oikos 2007, 116, 1438-1448.

26. Cao, C.Y.; Jiang, D.M.; Zhu, L.H.; Nan, Y.H. Degradation and diversity changes of meadow grassland in Keerqin Sandy Land. Atca Pratacult. Sin. 2006, 15, 18-26.

27. Yan, Q.L.; Liu, Z.M.; Zhu, J.J.; Luo, Y.M.; Wang, H.M.; Jiang, D.M. Structure, pattern and mechanisms of formation of seed banks in sand dune systems in northeastern Inner Mongolia, China. Plant Soil 2005, 277, 175-184.

28. Funes, G.; Basconcelo, S.; Diaz, S.; Cabido, M. Edaphic patchiness influences grassland regeneration from the soil seed-bank in mountain grasslands of central Argentina. Austral Ecol. 2001, 26, 205-212. [CrossRef]

29. Levassor, C.; Ortega, M.; Peco, B. Seed bank dynamics of Mediterranean pastures subjected to mechanical disturbance. J. Veg. Sci. 1990, 1, 339-344. [CrossRef]

30. Sacande, M.; Berrahmouni, N. Community participation and ecological criteria for selecting species and restoring natural capital with native species in the Sahel. Restor. Ecol. 2016. [CrossRef]

31. Tolvanen, A.; Laine, $\mathrm{K}$. The alpine soil seed standing vegetation bank in relation to field seedlings and in subarctic Finland. Arct. Antarct. Alp. Res. 2004, 36, 229-238.

32. Bruno, B. Dispersal-limited species-A challenge for ecological restoration. Basic Appl. Ecol. 2014, 15, 559-564.

33. Amiaud, B.; Touzard, B. The relationships between soil seed bank, aboveground vegetation and disturbances in old embanked marshlands of Western France. Flora 2004, 199, 25-35. [CrossRef]

34. González-Alday, J.; Marrs, R.H.; Martínez-Ruiz, C. Soil seed bank formation during early revegetation after hydroseeding in reclaimed coal wastes. Ecol. Eng. 2009, 35, 1062-1069. [CrossRef]

35. Matus, G.; Papp, M.; Tothmeresz, B. Impact of management on vegetation dynamics and seed bank formation of inland dune grassland in Hungary. Flora 2005, 200, 296-306. [CrossRef]

36. Tessema, Z.K.; de Boer, W.F.; Baars, R.M.T.; Prins, H.H.T. Influence of grazing on soil seed banks determines the restoration potential of aboveground vegetation in a semi-arid savanna of Ethiopia. Biotropica 2012, 44, 211-219. [CrossRef]

37. Sun, J.H.; Wang, Y.R.; Zeng, Y.J. Characteristics of the soil seed banks in degenerated grasslands under grazing and grazing suspension. Acta Bot. Boreali Occident. Sin. 2005, 25, 2035-2042.

38. Tong, C.; Feng, X.; Zhang, Y.M.; Zhong, Y.K. Soil seed banks in different grazing exclusion restoring succession stages in the Xiligole degraded steppe. Acta Ecol. Sin. 2008, 28, 1991-2002.

39. Zhang, J.Y.; Wang, Y.; Zhao, X.; Zhang, T. Grassland recovery by protection from grazing in a semi-arid sandy region of northern China. N. Z. J. Agric. Res. 2005, 48, 277-284. [CrossRef]

40. Bai, F.; Settles, A.M. Imprinting in plants as a mechanism to generate seed phenotypic diversity. Front. Plant Sci. 2015. [CrossRef] [PubMed]

41. Fernandez-Lugo, S.; de Nascimento, L.; Mellado, M.; Bermejo, L.A.; Arevalo, J.R. Vegetation change and chemical soil composition after 4 years of goat grazing exclusion in a Canary Islands pasture. Agric. Ecosyst. Environ. 2009, 132, 276-282. [CrossRef]

42. Gomaa, N.H. Soil seed bank in different habitats of the Eastern Desert of Egypt. Saudi J. Biol. Sci. 2012, 19, 211-220. [CrossRef] [PubMed]

(c) 2016 by the authors; licensee MDPI, Basel, Switzerland. This article is an open access article distributed under the terms and conditions of the Creative Commons Attribution (CC-BY) license (http:/ / creativecommons.org/licenses/by/4.0/). 